\title{
The Influence of Media and Technology on Gender Transformation and Divorce Rates in Indonesia
}

\author{
Nur Hidayati \\ \{nurhieday@gmail.com\} \\ Universitas Islam Negeri Sunan Ampel Surabaya
}

\begin{abstract}
The more years, the divorce rates in Indonesia has increased specifically. In conventional divorce, women were frequently regarded as objects or victims of divorce. But recently, the majority of women occupy the role as subjects who control divorce decisions. This study aim to reveal how the relationship of gender transformation and divorce phenomenon in Indonesia by statistical data, to describe divorce rates or numbers from the regions in Indonesia and the reasons why women today are brave to start divorce decisions and how media influence them. The agenda of gender awareness is transforming people's behaviour, especially women. $70 \%$ of divorce cases in Indonesia lead by women. Globalization helped socialize this issue on many occasions, both cultural and structural, by printed or digitalized media. These media change social, culture and political systems, including idiologies behind published content.
\end{abstract}

Keywords: divorce rates, gender transformation, Indonesia, media, technology, women.

\section{Introduction}

Mark Cammack, the professor from the South western School of Law, Los Angeles USA, based on his research, found that in the 1950s, divorce numbers in Southeast Asia, including Indonesia, are of the highest in the world. In 2010, Muslims Development of Ministry of Religion of Indonesia, found that from two millions of marriages every year in Indonesia, there were in the same year 285,184 cases of divorcement [1]. This shows how the more year, number of divorces in Indonesia increasingly even are at alarming level.

Based on data from The Central Statistics Agency (BPS), divorce rates in Indonesia in 2013 had reached 324,427 , which increased to 344,237 cases in 2014 , then go up to 347,256 in 2015 [2]. From this figure, research data emerged from the Indonesian Center for Religious Life Research and Development Agency, Ministry of Religion, in 2015 that the number of divorce cases filed by women reached 70\% [3]. It is interesting to discuss why in some regions, divorce cases were dominated by women's proposal rather than decided by men.

This changes bring us to reflect on the trend of women position in divorce. Today women are no more as object or victim in divorce. They are subjects who control the decision to save marriage or decide divorcement. This study is aimed to describe and analyze the influence media and gender transformation to the increasing number of divorces in Indonesia from year to year through statistics. 


\section{Discussion}

The word gender etymologically derived from English, which generally means sex [4] In the Oxford Online-Dictionary, gender is the state of being male or female (typically used with social and cultural references to rather than biological ones)[5]. Means, gender is a condition as a man or woman by referring more to differences of roles in culture and society, rather than physical differences.

While as a term, gender is a cultural concept which mentioned to make a difference in roles, behavior, mentality and emotional characteristics between men and women that develop in society [6]. The difference perspective at gender, according to Mansour Faqih, caused some inequality and injustice for men and especially women. The injustice occured because of the system or structure that lead to inequality for men and women is called gender injustice. Gender injustice occurs due to customary norms, government policies and religious interpretations and manifests in several interrelated things.

First, it started from marginalization, namely the process of impoverishment in economic aspects which caused a professional restrictions, where women are not permitted to access certain types of work. Secondly, the subordination or presumption that women are not important people for rights and having leadership from the domestic to political public affairs. Third, stereotyping or negative labeling. Fourth, violance both physical or mental so women will easily get a double burden.

The purpose of marriage is to form a happy and eternal family, as stated in Law No.1 of 1974 Articles. To achieve this goal, husband and wife as partners must pay attention to each other and maintain security, closeness and interdependence [7]. However, it does not rule out the possibility that the ideal be implemented all the time well. In chapter VIII article 38, it is stated that marriage can break up because of (a) death, (b) divorce and (c) the decision of judicial action. In addition to death, the divorce agreed by the court's decision can make the marriage interrupted, in which the provisions concerning divorce and adjudication of the court are stipulated in articles 39 and 40 [8].

Based on BPS data, it was found that provinces with the five highest divorce ratings in 2015 were Papua (34.93\%), East Java (27.83\%), Kep. Bangka Belitung (25.44\%), East Kalimantan (25.31\%), South Kalimantan (24.59\%). While the lowest five ranks were Maluku (8.07\%), North Maluku (9.35\%), Banten (9.81\%), Lampung (9.88\%), and South Sumatra $(10.12 \%)$ [9].

Based on BPS data about the percentage of divorce in Indonesia from 2013 to 2015 , wasfrom 2013 to 2014, a surge occured in 31 of 34 provinces in Indonesia. Then in 2014 toward 2015, the number increased in 32 of 34 provinces. This data showes that there has been a shift in values in the community related to marital problems, especially divorce. It is no longer a taboo thing to avoid in a marriage.

East Kalimantan, as the fourth highest province in divorce rates in Indonesia, based on the research of the provincial BPS showed that the cracks in households caused by several factors of separation: (1) disharmony $41.80 \%$, (2) third party interference $15.69 \%$, (3) no responbility 
$18.41 \%$, (4) economic factors $12.46 \%$, and others with each percentage no more than one percent.

Referring to the previous data that $70 \%$ of divorces in 2015 were proposed by women, a phenomenon emerged that women began to dare to position themselves as men. They realized their rights and dare to show their existence.Women no longer want to be confined to disharmony that occurs in the household. The wife chose to sue for divorce to defend her rights, by applying divorce to court, rather than maintaining marriage. If we compare the stereotypes of the past, this data shows the opposite fact. In the past a woman was labeled as timid person, especially that divorce would be harder to burden woman who called widow, compared to a man called widower.

The word media in the Indonesian Big Dictionary means a tool or a mean of technology means a scientific mothode to obtain practical goals, that is practical knowledge. Technology also means as each tool and source to provide some goods to cover human needs for their happy life [11].

There are two kinds of media from its shape and how to access, they are printed and digitalized media. While talking about media relates totechnology means digitalized media, such television, internet, and also social media which has growing tremendously since 2000s. With media and technology, human issues and cases in this global era spreaded fast and wide. That is also happen to the gender transformation issue.

Media run its power to influence and change some aspects from social, culture, even political sytem, included ideologies embedded behind the content of media. Television program through operas, telenovela, or drama, is a show that relies on teenages women to adults as their target market. In addition to non-reality shows, infotainment programs and reality shows have a high rating that also targets the market for adolescent to adult women, where the content of this event is often filled with celebrity household disputes that end in divorce.

Indah Wati in her study found that some divorce cases experienced by celebrity are interesting topic in infotainment, which is the most marketed program in almost television channel. The values and norm on divorce then not again looked as private family matter but to something to entertain public [12]. Infotainment in this case puts both information and entertainment to know idols deeper and closer for public figure's fans. Finally, divorce case is just a matter of entertaining news as well as other news to get closer and know more about idol artist.

While Wahyu Ernaningsih stated that the emergence of social media in the range of 2010 and up to today, have contributed to the actualization of women in cyberspace. The culture and rules that apply to a society or to a nation are inseparable from the influence of culture and environment in that community and the association of society [13]. Simply stated that media and technology has brought a social phenomenon concerning culture in a more modern, open and established gender awareness. The courage of the wife in filing for divorce, for the agenda of feminism, indicates women's awareness of their rights which began to increase. in the other hand, author does not state whether this phenomenon also a positive development for local wisdom and of eastern culture. 


\section{Conclusion}

Gender derived from English which means sex. As for the term, it is a cultural concept to make a difference in terms of roles, behavior, mentality and emotional characteristics between men and women that develop in society. Differences in looking at gender lead to inequality and injustice for men and especially women.

While the purpose of marriage is to form a happy and eternal family, not all rules listed in the law or religious law can be carried out ideally. Marriage can break up due to death, divorce and court decisions. Based on BPS data, the percentage of divorce in Indonesia from 2013 to 2015 experienced a surge, where $70 \%$ of divorces in 2015 were cases of divorce proposed by women. This cases were happened due to disharmony, third party disruption, no responbility, economic factors, and etc. This shows a shift in values in society related to marital problems, especially divorce. While the transformation agenda of gender awareness is able to change people's behavior, especially women who feel oppressed and become victims, globalization help this grow rapidly.

\section{References}

[1] Panjaitan, Deddy: This Is the Cause of the Highest Divorce in the World, in http://www.kompasiana.com/bangdepan/inilah-penyebab-perceraiantertinggi-di-indonesia 55094acaa3331122692e3965

[2] bps.go.id

[3] www.nu.or.id/post/read/72455/dibanding-cerai-talak-gugat-cerai-pada-6-tahunterakhir-jadi-tren

[4] Echols, John M. and Hassan Shadily: Kamus Inggris-Indonesia, Gramedia Pustaka Utama, Jakarta (2002)

[5] Oxford Online-Dictionary of English, www.oxforddictionaries.com

[6] Mas'udi, Masdar F. dkk: Feminisme: Belajar Memahami Gender, ISSS Press, Surabaya (T. Th).

[7] La Roe, Marlene Shelton and Lee Thrrick: Melestarikan Perkawinan, Dahara Prize, Semarang (1992)

[8] The Marriage Convention No.1, articles 39 and 40 (1974)

[9] www.bps.go.id

[10] kbbi offline

[11] kbbi offline

[12] Wati, Indah: Wacana Perceraian dan Selebriti Perempuan dalam Program Talkshow Hitam Putih di Trans7, Commonline Departemen Komunikasi, vol. $3 /$ no. 3.

[13] Ernaningsih, Wahyu: Polemik dan Isu Gender dalam Kasus Perceraian di Kota Palembang, dalam eprints.unsri.ac.id 